\title{
Traditional Knowledge as a Basis for the Development of a Sustainable Resource Management Program: A Case Study in a Rural Village in Morelos, Mexico
}

\author{
Rubén Hernández-Tapia ${ }^{1}$, Teresa Valverde ${ }^{2}$, Abel Aranda $^{1}$, Concepción Martínez-Peralta ${ }^{1}$, and Diana Platas-Neri ${ }^{1 *}$ \\ ${ }^{1}$ School of Superior Studies of Jicarero, Autonomous University of the State of Morelos, Jojutla, Morelos, Mexico. \\ ${ }^{2}$ Department of Ecology and Natural Resources, Faculty of Science, National Autonomous University of Mexico, Mexico City, \\ Mexico. \\ *diana.platas@uaem.mx
}

\begin{abstract}
We analyzed the traditional knowledge and management of local wild fauna and flora among the inhabitants of the peasant community of Chimalacatlán, together with their perception of local environments, to identify potential species for the future development of a sustainable resource management program. Initial contact with the community was established through an ethnographic survey to identify those with the most knowledge on this topic. Residents were selected for inclusion in the interviews using chain referral sampling. Forty-eight people were interviewed and asked about the species they were familiar with, as well as their methods of fostering/managing some of them. In this context, people cited 83 plant and 44 animal species. The preferred animals for the development of a resource management program were Odocoileus virginianus (white-tailed deer) and Ctenosaura pectinata (Mexican spiny-tailed iguana); while the preferred plants were Amphipterygium adstringens (cuachalalate) and Bursera linanoe (linaloe). For the residents of this community, fauna and flora have constituted an important resource, since various species are used as food, medicinal remedies, firewood, ornaments, and pets. Some species are illegally hunted and/or marketed as a means of subsistence. This study confirms the value of local residents' knowledge in improving the management of environmental units, as well as the need to strengthen collaboration between decision-makers in development programs and the community.
\end{abstract}

Received January 12, 2017

OPEN ӘACCESS

Accepted November 27, 2017

DOI 10.14237/ebl.9.2.2018.870

Keywords Community programs, Ethnobiology, Environmental perception, Sustainable resource management, Traditional knowledge

Copyright (C) 2018 by the author(s); licensee Society of Ethnobiology. This is an open-access article distributed under the terms of the Creative Commons Attribution-NonCommercial 4.0 International Public License (https://creativecommons.org/licenses/by-nc/4.0), which permits non-commercial use, distribution, and reproduction in any medium, provided the original author and source are credited.

Supplementary Files available at ojs.ethnobiology.org/index.php/ebl/rt/suppFiles/870

\section{Introduction}

The biological knowledge of the local inhabitants of protected areas should be taken into account as central elements in the development of government programs aimed at the conservation and sustainable management of these areas (Ortega-Argueta et al. 2016; Weber et al. 2006). In support of this, there is growing evidence that the success of environmental programs and sustainable resource management projects greatly benefits from the active participation of local inhabitants (Haenn 1999; Ortega-Argueta et al. 2016; Ramires et al. 2012; Weber et al. 2006). Moreover, local inhabitants possess key environmen- tal and strategic information for designing and running these programs (Garibaldi and Turner 2004; Ramires et al. 2012). Accordingly, the involvement of local residents decreases the uncertainty around the success and effectiveness of these programs (Kellert et al. 2000; Ramires et al. 2012; Vandebroek et al. 2011).

With this in mind, we used an ethnobiological approach to document and analyze the traditional knowledge of a peasant community in the Mexican state of Morelos, their perceptions and feelings towards the plant and animal species with which they interact, and the way the latter influence their 


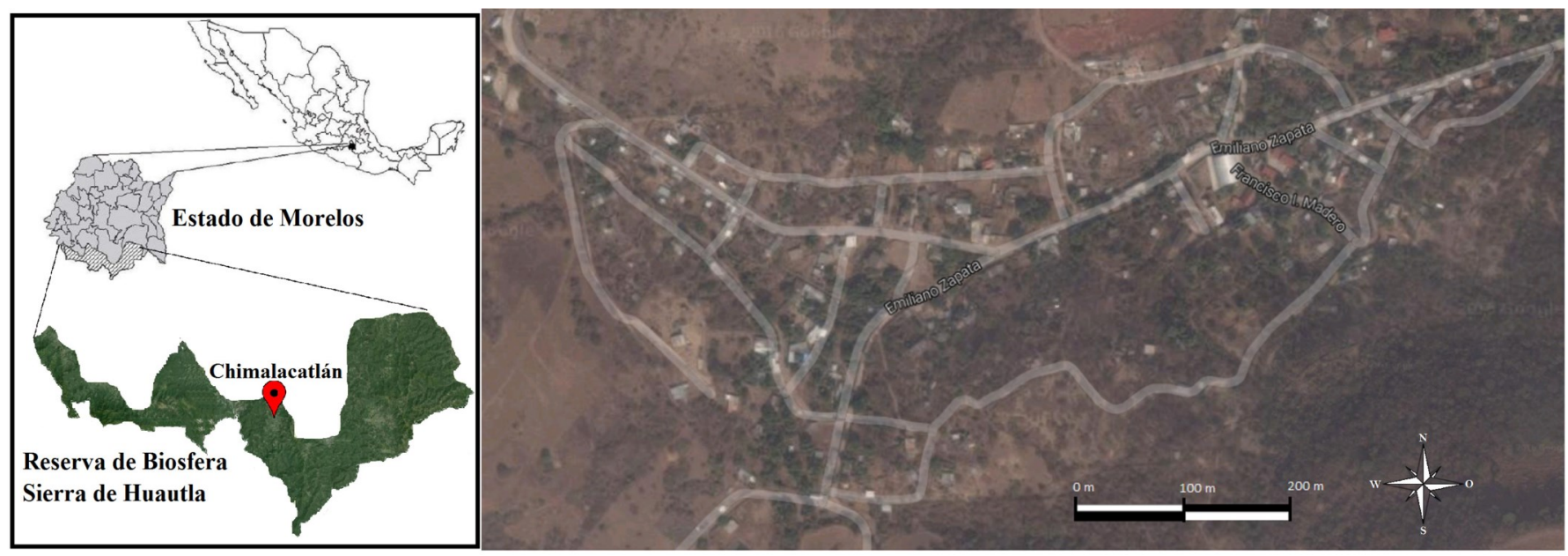

Figure 1 The study site, the village of Chimalacatlán, is in south-central Mexico, south of Morelos State.

decisions on natural resource acquisition and management (Bohensky and Maru 2011; Bohensky et al. 2013; Marques 2001). We aimed to identify potential plant and animal species that could be the focus for the future development of sustainable resource management programs.

The state of Morelos, located in southwestern Mexico, is a highly biodiverse area with an extremely elevated deforestation rate. It is estimated that by $1990,60 \%$ of the original vegetation cover had been lost (Trejo and Dirzo 2000). As a result, 123 plant and animal species from this state have been listed as threatened (CONABIO and UAEM 2006). The major driving force of this transformation process throughout Mexico, has been land-use change towards agriculture, farming, and urban growth (CEAMA-CONABIO 2003). In response to this general trend towards biodiversity loss, the Mexican government has created public policies that encourage the diversification of resource management systems in rural areas (CONABIO 2012; Rubio-Becerra 2012). These initiatives include ongoing regional programs aimed at wildlife management. These are referred to as 'Management Units for the Conservation and Sustainable Use of Wildlife' (in Spanish, 'Unidades de Manejo para la Conservación y Aprovechamiento Sustentable de la Vida Silvestre', spanish acronym: abbreviated as 'UMA') (Robles-de Benito 2009; SEMARNAT 2015). All too often, however, the establishment of an UMA is the result of government decisions and actions that seldom take into account the views and choices of the local people (OrtegaArgueta et al. 2016; Weber et al. 2006). Consequently, these units often fail to respond to the actual needs and preferences of local communities and thus they eventually fall into disuse, resulting in a regrettable waste of money, effort, and time (Ortega-Argueta et al. 2016; Weber et al. 2006).

Our study community is located within the boundaries of the Sierra de Huautla Biosphere Reserve, designated as such in 1999 and recognized by UNESCO through the Man and Biosphere Program (CONANP 2005). This designation was achieved with the participation of a local university: The Autonomous University of Morelos State (UAEM) and the authorities (Durand and Vázquez 2011; López -Medellin et al. 2017). However, protected areas are established in complex social scenarios, and although they contemplate social participation as a fundamental element, communities often have very little knowledge about the purposes and activities of the reserves, and limited involvement in their management (Brandon et al. 1998; Durand 2010; Durand and Vázquez 2011). It is therefore of paramount importance to make an effort to secure the active participation of local residents in launching any sustainable resource management project in the area. People must be taken into account for any resource management project to be sustainable, since they are the main executors of the action on which the project is based (Berkes 2009; Durand and Vázquez 2011; Robles-de Benito 2009). This study represents a step in that direction for an UMA project in the state of Morelos.

\section{Methodology}

Study Site

This study was conducted in the community of Chimalacatlán, in the south-central portion of the 
Mexican state of Morelos at an altitude of 1,130 masl (INEGI 2015) (geographic coordinates: 180 27' 48.0" $\mathrm{N}$; 99० 05' 30.6" W; Figure 1). The climate is warm and subhumid with a summer rainy season $\left(A w o^{\prime \prime}(w)\right.$ (i)g, sensu García 1981; CONANP 2005). Annual precipitation is approximately $900 \mathrm{~mm}$, while the mean annual temperature is approximately $22.6{ }^{\circ} \mathrm{C}$. Chimalacatlán is located within the Sierra de Huautla Biosphere Reserve (CONANP 2005), mainly covered with seasonally dry tropical forest with a high diversity of vascular flora (CONANP 2005). The plant families Fabaceae Lindl., Poaceae Barnhart, Asteraceae Bercht. and J. Presl and Burseraceae Kunth are the best represented, and some of the dominant tree species in the region include Con₹attia multiflora (B. L. Rob.) Stanld., Lysiloma acapulcensis (Kunth), L. divaricatum (Jacq.) J. F. Macbr., Bursera sp. Jacq. Ex L., and Ceiba sp. Mill. (CONANP 2005). In disturbed areas, a secondary forest dominated by thorny legumes (e.g., Acacia farnesiana (L.) Willd., $A$. bilimekii J.F. Macbr., $A$. cocbliacantha Humb. and Bonpl. ex Willd., A. pennatula (Schltdl. \& Cham.) Benth., Pithecellobium_acatlense Benth. and Mimosa polyantha Benth.) (Pérez-Jiménez et al. 1992) has regrown. Faunistic records list eight fish species, 11 amphibians, 52 reptiles, 220 birds, and 66 mammals (CONANP 2005). At least 40 vertebrate species (excluding fishes) are considered threatened (CEAMISH 1993).

Chimalacatlán, belonging to the municipality of Tlaquiltenango, is among the poorest communities in Morelos (at least $25 \%$ of its population live in extreme poverty, and educational facilities are limited) (INEGI 2015). There is some degree of communal land management, in which an assembly oversees several administrative matters.

\section{Ethnographic survey}

Initial contact with community members was established through informal visits to local residents' homes to explain the purpose of the research and to identify those with the best knowledge of the local flora and fauna, and resource management. Residents were selected to be interviewed using chain referral sampling (also called snowball sampling [Biernacki and Waldorf 1981; Heckathorn 2002]). In keeping with this system, sampling began by interviewing the householder, i.e., the person 'in charge' of a household in the sense that $\mathrm{s} /$ he is the main provider and the key decision maker. We began with the householders, since, according to the community, they are the main possessors of ethnobiological knowledge given their livelihood as farmers and therefore their contact with nature. After the interviews had been completed, respondents suggested other individuals who could be interviewed based on the criteria of being local community residents.

The village of Chimalacatlán is composed of 384 local inhabitants distributed among 96 households. A semi-structured interview was applied to 48 householders, 46 men and two women. Sample size was determined using the method explained by Spiegel and Stephens (2005).

Interviews were applied between October and December 2015 and covered the following topics: general information, socio-economic aspects, sociocultural aspects, and perception of the importance of animal and plant species as potential management targets (for the complete interview, see Appendix 1).

\section{Data analysis}

The results of the interviews were concentrated in a database from which general statistics were obtained. In addition, a correlation table was obtained between all possible pairs of continuous variables from the socio-economic and socio-cultural sections to identify significant associations between various features of the community (Spearman Rank Order Correlation square matrix).

In relation to respondents' perception of the importance of local flora and fauna, a list of all the species mentioned was drawn up, including their common names (by which local people refer to them, either in Spanish, Náhuatl, or in some cases, a combination of both) and their scientific names. We verified the correspondence between common and scientific names using the descriptions people gave of the different plants and animals and corroborated their identity using published lists of local flora and fauna (CEAMISH 1993; CONANP 2005).

The most renowned species were identified (i.e., those that were mentioned by at least $30 \%$ of respondents) and Generalized Linear Models (GLM) were run between each of them (as a categorical variable: mentioned vs. not mentioned) and the continuous variables comprising the socio-economic and socio-cultural profiles (e.g., age, educational attainment, number of children, number of household members). This allowed us to evaluate which aspects of these profiles were significantly related to people's choice of particular animal and plant species during 
Table 1 General statistics obtained from respondents on their socio-economic and socio-cultural aspects.

\begin{tabular}{llllllll}
\hline & $\begin{array}{l}\text { Age } \\
(\mathbf{y r})\end{array}$ & $\begin{array}{l}\text { Educational } \\
\text { attainment }^{\mathbf{a}}\end{array}$ & $\begin{array}{l}\text { No. of } \\
\text { children }\end{array}$ & $\begin{array}{l}\text { No. of people } \\
\text { in household }\end{array}$ & $\begin{array}{l}\text { No. making } \\
\text { decisions }\end{array}$ & $\begin{array}{l}\text { Environmental } \\
\text { knowledge }^{\mathbf{b}}\end{array}$ & $\begin{array}{l}\text { Interest in } \\
\text { UMA }^{\mathbf{c}}\end{array}$ \\
\hline Means & 49.96 & 7.04 & 3.29 & 3.67 & 1.37 & 3.37 & 3.46 \\
SD & $(2.19)$ & $(0.41)$ & $(0.33)$ & $(0.25)$ & $(0.07)$ & $(0.12)$ & $(0.11)$ \\
Range & $23-83$ & $1-12$ & $0-8$ & $1-9$ & $1-2$ & $1-5$ & $1-5$ \\
\hline
\end{tabular}

an terms of the number of school years finished. Elementary school consists of six years; middle school is three years; and high school is three years.

${ }^{\mathrm{b}}$ Refers to a self-evaluation with figures ranging from one (low) to five (high).

' $R$ efers to a self-evaluation with figures ranging from one (low) to five (high).

For a detailed description of variables, see Appendix 1.

the interviews. Statistical tests were conducted using Statistica 8 (Statsoft.com).

\section{Results}

Ethnographic survey

The average age of the sample was 50 years old, with ages ranging from 23 to 83 (Table 1). All of them were 'mestizos' (i.e., of mixed indigenous and European descent). Educational attainment varied widely; $67.0 \%$ of respondents had completed elementary school, and $43.7 \%$ had finished middle school. Seven people $(14.6 \%)$ had no children, while $33.0 \%$ had five or more. The vast majority were Roman Catholics (92.0\%; Appendix 2). Most households were composed of the nuclear family only, though some of them also included members of the extended family, or the spouses of one or two of their children. As they become adults, most men who stay in the village eventually marry, settle down and make a living as farmers (in agriculture and / or cattle farming).

In relation to how decisions are made in the household, most people reported that they alone made the decisions $(60.4 \%)$, although some stated that both they and their spouse decided together. A high proportion $(48.0 \%)$ considered themselves to have a very good or a reasonably good knowledge of the environment $(x=3.4,1<x<5)$, while $54.0 \%$ of them expressed great or very great interest in the establishment of an UMA in Chimalacaltán (with an average of 3.5 , on a scale of 1 to 5) (Table 1).

\section{Correlations between ethnographic variables}

Results from the Spearman Rank Order Correlation show that educational attainment negatively correlates with age: younger people tend to have higher education (Table 2). Moreover, older people tend to have more children than younger people, and the number of children negatively correlates with educational attainment: more highly educated people have fewer children than people with lower educational attainment. Predictably, people who have more children live in households with a higher number of members, and higher educational attainment is associated with more crowded

Table 2 General statistics obtained from respondents on their socio-economic and socio-cultural aspects.

\begin{tabular}{|c|c|c|c|c|c|c|}
\hline & $\begin{array}{l}\text { Educational } \\
\text { attainment }\end{array}$ & $\begin{array}{l}\text { No. of } \\
\text { children }\end{array}$ & $\begin{array}{l}\text { Household } \\
\text { members }\end{array}$ & $\begin{array}{l}\text { No. of decision } \\
\text { makers }\end{array}$ & $\begin{array}{l}\text { Knowledge of } \\
\text { environment }\end{array}$ & Interest in UMA \\
\hline Age (years) & -0.651 & 0.546 & -0.127 & -0.268 & -0.246 & -0.076 \\
\hline $\begin{array}{l}\text { Educational } \\
\text { attainment }\end{array}$ & & -0.434 & 0.299 & 0.298 & 0.229 & 0.023 \\
\hline No. of children & & & 0.292 & -0.108 & -0.239 & -0.018 \\
\hline $\begin{array}{l}\text { Household } \\
\text { members }\end{array}$ & & & & 0.306 & 0.156 & 0.19 \\
\hline $\begin{array}{l}\text { No. of decision } \\
\text { makers }\end{array}$ & & & & & -0.199 & 0.207 \\
\hline $\begin{array}{l}\text { Knowledge of } \\
\text { environment }\end{array}$ & & & & & & 0.449 \\
\hline
\end{tabular}

Figures are Spearman Rank $R$ coefficients, which vary between 1 and -1 , with values approaching 0 when there is no correlation between variables. Significant correlations $(P<0.05)$ are marked in bold. 


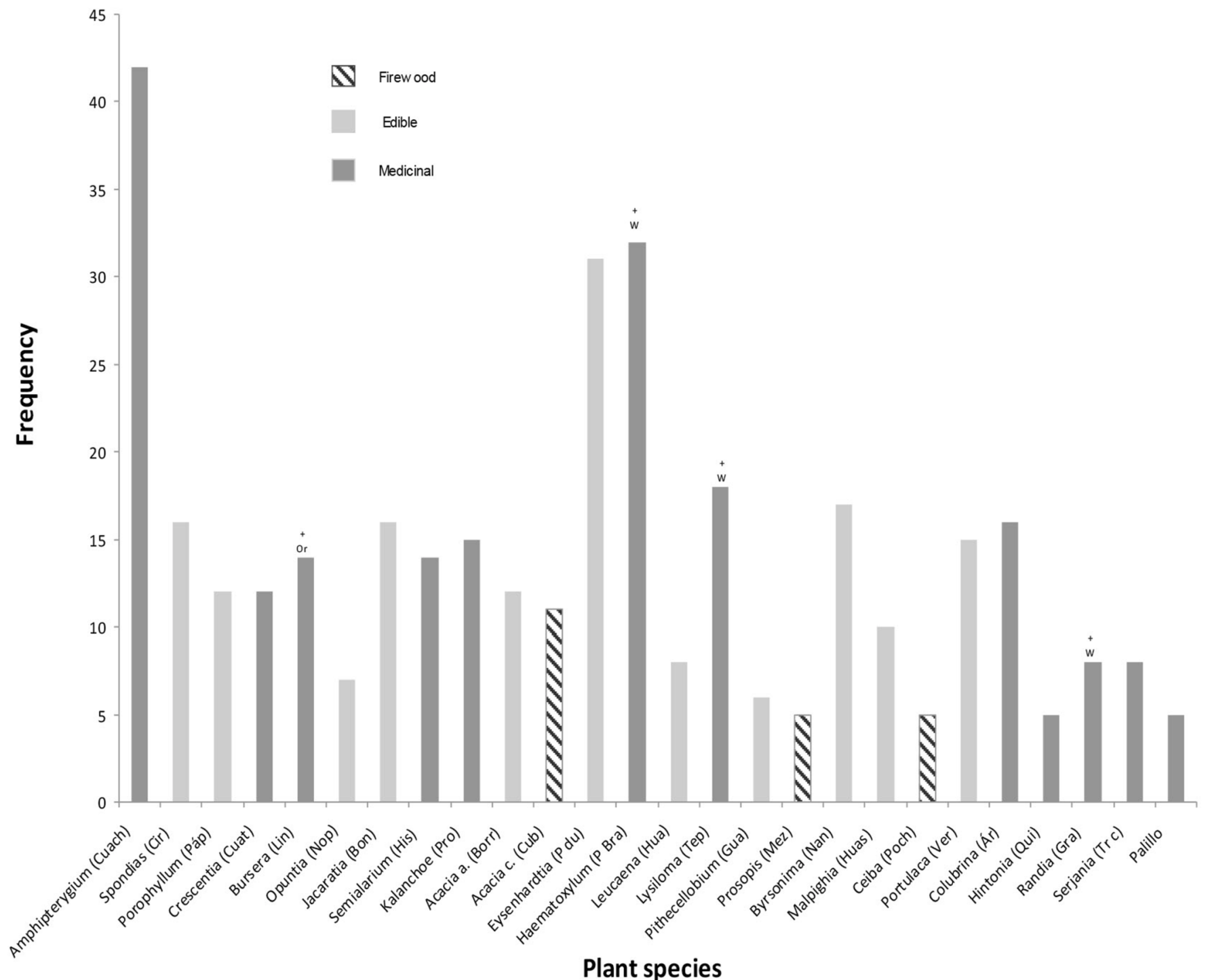

Figure 2 Number of times each plant species was mentioned during the interviews (frequency). Column shade refers to the main use of each species; when several uses were recognized, the relevant column is marked with + and the initials of the secondary use ( $\mathrm{Me}=$ medicinal, $\mathrm{Or}=$ ornamental). Species are named according to their genus in Latin (see Appendix 3 ), and the first letters of the common name are shown in parenthesis (see Appendix 3).

households (Table 2). It is interesting that householders with lower educational attainment often state that they alone make the decisions at home, while householders with higher educational attainment more often declare that decisions at home also involve others. Lastly, people that consider themselves more knowledgeable about the environment tend to have greater interest in the establishment of an UMA (Table 2).

Perception of the community situation

The main challenges perceived by respondents in
Chimalacatlán are of economic origin (85.4\%); only $2.1 \%$ considered that environmental problems are the main challenge facing their community (Appendix 2). However, when asked about the near future (i.e. in 20 years' time), a much higher number of people $(32.0 \%)$ identified environmental issues as a potential cause for concern. Species loss $(40.0 \%)$ and climate change $(33.0 \%)$ were the most frequently mentioned environmental problems (Appendix 2). The main environmental degradation factors mentioned were pollution $(37.5 \%)$, deforestation $(25.0 \%)$, and illegal hunting and fishing $(29.2 \%)$. Yet when asked about 


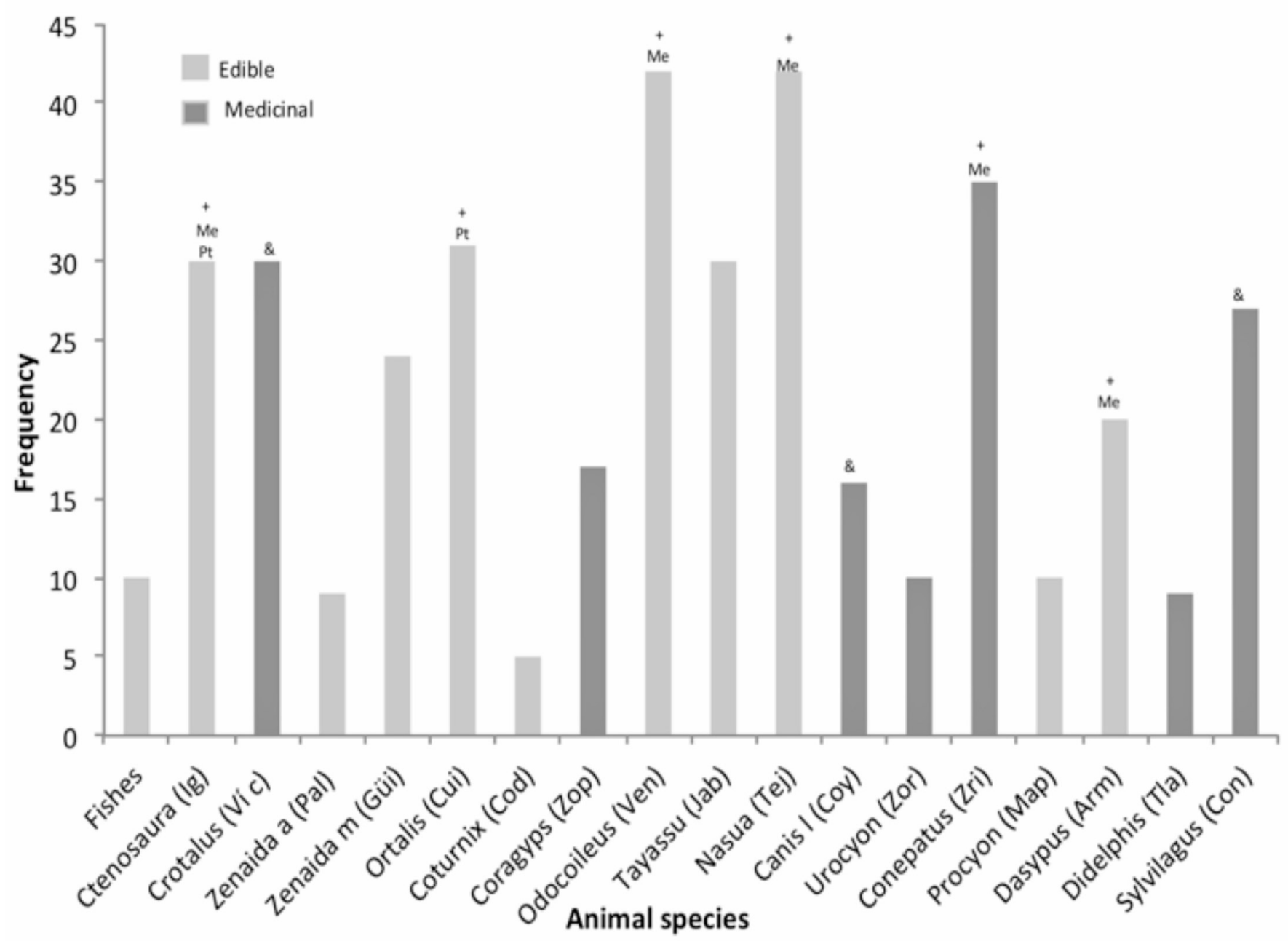

Figure 3 Number of times each animal species was mentioned during the interviews (frequency). Column shade refers to the main use of each species; when several uses were recognized, the relevant column is marked with + and the initials of the secondary use $(\mathrm{Pt}=$ pet, $\mathrm{Me}=$ medicinal). The $\&$ symbol indicates unwanted species. Species are named according to their genus in Latin, the first letters of the common name are shown in parentheses (see Appendix 3 ).

the latter, only $18.7 \%$ of respondents admitted to having direct acquaintance with poachers, whose main aim is either commercial gain or home consumption; a much higher proportion $(47.9 \%)$ were aware of people who harvest plant species and commercialize them one way or another.

\section{Relationship with the local flora and fauna}

Respondents mentioned a total of 83 plant species and 44 animal species, which they considered important (Appendix 2 and Appendix 3). Most of them are native to the area, although a few correspond to exotic species (i.e. introduced), valued mainly because of their ornamental or medicinal uses (e.g. Eucalyptus sp. L’Hér., Aloe vera (L.) Burm. F.).
Of the 83 plant species mentioned, $26(31.3 \%)$ were named by five people or less (Fig. 2), and only 10 species $(12.0 \%)$ were named by at least 15 people (i.e., $30.0 \%$ of respondents). The latter group will be referred to, from now onwards, as the renowned species, popular either because they are edible (5 species), or have medicinal uses (5 species) (Figure 2).

Of the 44 animal species people named, fewer than half (18 species, $41.0 \%$ ) were mentioned by five or less people (Fig. 3). Twelve species (27.2\%) belonged to the category of renowned species (named by at least $30.0 \%$ of respondents). The reason for this is that most of them are edible (8 species) and/or medicinal (8 species) (Figure 3). 
The number of renowned animal species mentioned by respondents directly correlated with their level of environmental knowledge, and interest in the establishment of an UMA (Table 3). However, the number of renowned plants mentioned was mainly associated with the number of renowned animals. However, other factors also had some association with this variable: people with a greater interest in the establishment of an UMA, as well as those with higher educational attainment tended to name a larger number of renowned plant species (Table 3); and interestingly, older people tended to name a smaller number of renowned species than younger people (Table 3).

\section{Discussion}

The aim of our study was to assess the knowledge the Chimalacatlán people have of their local fauna and flora, as well as evaluate their perceptions and customs regarding natural resource acquisition and management, to identify potential animal and plant species for the establishment of an UMA. Previous studies had clearly established the need for social participation as a key element of these projects, and recognized the value of ethnobiological knowledge, the incorporation of community needs, and the provision for shared responsibilities between government and community (Berkes 2009; Garibaldi and Turner 2004; Ortega-Argueta et al. 2016).

In our study, Chimalacatlán residents acknowledged the importance of 83 plant and 44 animal species, most of which are native to the area. We correlated this information with cultural and economic aspects to gain insight into how these variables could impact the potential establishment of an UMA. The ethnographic approach has allowed us to deepen our understanding of the ethnobiological aspects that are crucial to supporting efficient resource management measures in such a way that local inhabitants can understand and accept them.

Ethnographic survey

Compared to national demographic records, the sample population is a relatively mature (in terms of average age and population structure) and welleducated group of people (Table 1). This does not reflect the general situation of Chimalacatlán, as respondents were chosen on the basis of the likelihood that they would be able offer valuable insights into the potential establishment of an UMA. The fact that younger people had higher educational attainment than older people (Table 2) may reflect a developing society with increasing access to education. These demographic trends may promote greater participation by youth within the community, as they may become active agents of social change (Durkheim 1968; Oehmichen 2000).

The average number of children per family among respondents (3.3) was much higher than the national average (2.2), as one would expect for a rural area in Mexico. However, average household size (3.7) was slightly lower than the national mean (3.9). The fact that nearly $40 \%$ of householders decide together with their spouses is quite unusual for a rural community in Mexico, since men are traditionally the main providers and decision makers (Galeski 1977). However, Morelos' rural societies are rapidly changing partly as a result of migration. Together with higher educational achievement and greater concern about the environment, we are seeing a shift in gender issues (Saldaña-Fernández et al. 2007; Sánchez-Saldaña 2008).

Table 3 Correlation table between the different continuous variables comprising the socio-economic and socio-cultural profiles (as in Table 2), and number of renowned ${ }^{*}$ animal and plant species mentioned in the interview. Figures are Spearman Rank $R$ coefficients (details as in Table 2). Significant correlations $(P<0.05)$ are marked in bold. Correlations with significance levels of $0.07^{\&}, 0.09^{+}$and $0.10^{\#}$ are also noted.

\begin{tabular}{|c|c|c|}
\hline & No. of renowned ${ }^{*}$ animals mentioned & No. of renowned ${ }^{*}$ plants mentioned \\
\hline Age (years) & -0.107 & $-0.275^{\&}$ \\
\hline Educational attainment & 0.162 & $0.243^{\#}$ \\
\hline No. of children & -0.059 & -0.102 \\
\hline Household members & 0.165 & -0.009 \\
\hline No. of Decision-makers & 0.069 & 0.201 \\
\hline Knowledge of environment & 0.404 & 0.128 \\
\hline Interest in UMA & 0.336 & $0.251^{+}$ \\
\hline No. of renowned ${ }^{*}$ animals mentioned & & 0.566 \\
\hline
\end{tabular}

*Renowned animal and plant species are defined here as those mentioned by at least $30 \%$ of the population sample. 
As in many rural Mexican villages, in Chimalacatlán, most women are housewives, while children and youth go to school and help out with household chores and farming jobs. Many of them eventually emigrate to big cities or to the United States (especially men), in search of better education or job opportunities. Migration from rural to urban areas creates complex dynamics, such as the fragmentation of community life and a change in priorities, since survival and adaptation to new situations become central concerns (Giménez 1994; López-Medellin et al. 2017; Medina 1996; Robson and Berkes 2011; Saldaña-Fernández et al. 2007).

As mentioned earlier, most of the men who stay in the village eventually marry, settle down, and make a living as farmers. These people interact intensively with the local wildlife since, in addition to farming activities, they harvest other resources for direct consumption or to supplement the household economy (such as fishing, hunting, fruit picking, firewood collection and so on). They also often become involved in decision making in relation to politics and resource management in the community.

We observed that agricultural land plots are socio -cultural units around which many aspects of community life are organized, such as the agricultural cycle and associated customs and rituals, which consolidate the relationship between local inhabitants and their environment. Traditionally, these agricultural units have also affected the gender division of labor, family relations, and economic and political principles in the community (Medina 1995, 1996).

\section{Perception about the community's situation}

As shown by our results, people perceive that the most important challenges in Chimalacatlán are economic whereas environmental problems are not really a major concern (only $4.0 \%$ of respondents identified environmental degradation as the main challenge facing the community). The reason for this may be that environmental changes occur slowly and people are not necessarily aware of or worried about them. Moreover, people's immediate concerns revolve around everyday needs such food and shelter. However, a high proportion of respondents mentioned that environmental challenges are likely to be a key concern in the near future. For instance, although some people mentioned that they notice dams are emptier and that the rainy season is shorter

Hernández-Tapia et al. 2018. Ethnobiology Letters 9(2):1-11 than a few years ago; since they still manage to make a living, they tend to frame these worries in the future tense.

Our results showed that in Chimalacatlán, 85.0\% of respondents regarded economic problems as the main challenge facing the community. Indeed, public policies have aggravated economic tension in rural areas. For instance, government support for economic development in these regions has decreased dramatically over the past few decades, while access to direct natural resource management has gradually been restricted (Calva 2001; Fox and Haight 2010; Guzmán-Gómez and León-López 2014). Accordingly, we consider that the establishment of an efficient, community-managed UMA could generate cooperative processes, reactivate local production and thus satisfy local needs for both social network building and economic stability. A community managed model, despite its potential for social conflict, could generate economic gain and assistance in natural resource management (López-Medellin et al. 2017). We are aware this is a major area of discussion in both academic and social contexts. In this article, we limit our considerations on this issue to the local situation of the Chimalacatlán community.

\section{Relationship with the local flora and fauna}

The plant species we recorded are used as food, medicine, ornamental, or firewood (their use as building material and fodder were not mentioned). The fact that people harvest edible plants for direct consumption is a sign of a resilient food system that contributes to the stability of the community in social and cultural terms. Medicinal plants are part of traditional therapeutics, which has empirical, ritual and religious elements. People allow these plants to grow freely on their agricultural plots, home gardens, and adjacent lands; or else know where to find them in the wild. This denotes a systematic observation of the environment and a transmission of knowledge from generation to generation.

The concept of wild fauna refers to nondomesticated animals with which people interact either directly or indirectly in their natural environment. In Chimalacatlán, many wild animals are important resources that function mainly as food complements, but also as remedies. However, there is a widely-held perception that overexploitation may result in species loss. Our results showed that 29.0\% of respondents thought that illegal hunting and fishing were key factors in environmental degradation. This is 
an issue that warrants further analysis in future studies.

Relevance in terms of resource use and the potential establishment of a UMA

According to the perception of local residents, a UMA community project could enhance social and economic development in Chimalacatlán by expanding people's opportunities for participation and indirectly generating jobs (López-Medellin et al. 2017). In principle, it is thought that emphasizing residents' participation has the potential to benefit wildlife conservation and sustainable resource management (Durand and Vázquez 2011; LópezMedellin et al. 2017). Accordingly, our study shows the value of traditional knowledge in the potential establishment and management of UMAs. A promising investment, according to local residents' preferences and traditional use, would be an UMA focused on the captive breeding and commercialization of the Mexican spiny tailed iguana (Ctenosaura pectinate Wiegmann), together with the cultivation of certain wild plants such as Amphipterygium adstringens (Schltdl.) Standl. (cuachalalate), Haematoxylum brasiletto H. Karst. (Brazil wood) and Bursera linanoe (La Llave) Rzed., Calderón and Medina (bursera). Comanagement systems (such as coordinated civil projects) would seem to be the most appropriate means of strengthening the interplay between conservation and sustainability (Berkes 2009; Biskupovic 2015).

\section{Acknowledgements}

This study was funded through a studentship to RHT and support to publish in open access. We would like to thank Mr. Nagapriya Wright for his helpful comments on the manuscript. We are also grateful to the Tapia family for their hospitality and support during the fieldwork. We are indebted to those who were so generous with their time and agreed to be interviewed over the course of the research.

\section{Declarations}

Permissions: None declared.

Sources of funding: None declared.

Conflicts of Interest: None declared.

\section{References Cited}

Biskupovic, C. 2015. From Rural Haven to Civil

Political Project: Utopian Ideals and Environmental Protection in the Precordillera, Santiago, Chile.
Journal of Political Ecology 22:183-198. Available at: https://journals.uair.arizona.edu/index.php/JPE/ article/view/21084. Accessed on December 5, 2017.

Berkes, F. 2009. Evolution of Co-Management: Role of Knowledge Generation, Bridging Organizations and Social Learning. Journal of Environmental Management 90:1692-1702. DOI:10.1016/ j.jenvman.2008.12.001.

Biernacki, P., and D. Waldorf. 1981. Snowball Sampling: Problems and Techniques of Chain Referral Sampling. Sociological Methods Research 10:141-63. DOI:10.1177/004912418101000205

Bohensky, E. L., and Y. Maru. 2011. Indigenous Knowledge, Science, and Resilience: What Have We Learned From a Decade of International Literature on 'Integration'? Ecology and Society 16:624. DOI:10.5751/ES-04342-160406.

Bohensky, E. L., J. R. A. Butler, and J. Davies. 2013. Integrating Indigenous Ecological Knowledge and Science in Natural Resource Management: Perspectives from Australia. Ecology and Society 18:20-25. DOI:10.5751/ES-05846-180320.

Brandon, K., K. H. Redford, and S. E. Sanderson, eds. 1998. Parks in Peril: People, Politics, and Protected Areas. Island Press and The Nature Conservancy, Washington, DC.

Calva, J. L. 2001. México Más Allá del Neoliberalismo: Opciones Dentro del Cambio Global. Plaza and Janés, Mexico.

Centro de Educación Ambiental e Investigación de la Sierra de Huautla (CEAMISH). 1993. Resumen del programa de manejo de la Sierra de Huautla. Centro de Educación Ambiental e Investigación de la Sierra de Huautla, Cuernavaca, Morelos, Mexico.

Comisión Nacional para el Conocimiento y Uso de la Biodiversidad and Universidad Nacional del Estado de Morelos (CONABIO and UAEM). 2006. La Diversidad Biológica en Morelos: Estudio del Estado. Comisión Nacional para el Conocimiento y Uso de la Biodiversidad and Universidad Nacional del Estado de Morelos, Cuernavaca, Morelos, Mexico.

Comisión Estatal del Agua y Medio Ambiente and Comisión Nacional para el Conocimiento y Uso de la Biodiversidad (CEAMA and CONABIO). 2003. Estrategia estatal sobre biodiversidad de Morelos. Comisión Estatal del Agua y Medio Ambiente and Comisión Nacional para el Conocimiento y Uso de 
la Biodiversidad, Cuernavaca, Morelos, Mexico. Available at: http://www.biodiversidad.gob.mx/ region/EEB/pdf/EEB_Morelos_2003.pdf. Accessed on December 5, 2017.

Comisión Nacional para el Conocimiento y Uso de la Biodiversidad (CONABIO). 2012. Proyecto de Evaluación de las Unidades de Manejo para la Conservación de la Vida Silvestre (UMA) (1997-2008). Resultados de la Fase I: Gestión y Administración. Proyectos CONABIO: HV003, HV004, HV007, HV012 and HV019. Comisión Nacional para el Conocimiento y Uso de la Biodiversidad (CONABIO), Mexico. Available at: http:// www.biodiversidad.gob.mx/usos/UMAs_pdf/ Informe_CONABIO_Proyecto_UMA_FASE_I.pdf. Accessed on December 5, 2017.

Comisión Nacional de Áreas Naturales Protegidas (CONANP). 2005. Programa de Conservación y Manejo. Reserva de la Biosfera Sierra de Huautla. CONANP-SEMARNAT, Mexico City, Mexico.

Durand, L. 2010. Pensar Positivo no Basta. Actitudes en Torno a la Conservación en la Reserva de la Biosfera Sierra de Huautla, México. Interciencia 35:430-436. Available at: http://www.redalyc.org/ articulo.oa?id=33913158006. Accessed on December 5, 2017.

Durand, L., and L. B. Vázquez. 2011. Biodiversity Conservation Discourses. A Case Study on Scientists and Government Authorities in Sierra de Huautla Biosphere Reserve, Mexico. Land Use Policy 28:76-82. DOI:10.1016/ j.landusepol.2010.04.009.

Durkheim, E. 1968. Las Reglas del Método Sociológico y Otros Escritos Sobre Filosofía de las Siencias Sociales. Alianza Editorial, Madrid, Spain.

Fox, J., and L. Haight, coords. 2010. Subsidios Para la Desigualdad: Las Politicas Públicas del Maín en México a Partir del Libre Comercio. Woodrow Wilson International Center for Scholars, Mexico. Available at: https://www.wilsoncenter.org/sites/ default/files/Subsidios $\% 20 \mathrm{Para} \% 20 \mathrm{La} \%$ 20Desigualdad.pdf. Accessed on December 5, 2017.

Galeski, B. 1977. Sociología del Campesinado. Editorial Península, Barcelona, Spain.

García, E. 1981. Modificaciones al Sistema de Clasificación Climática de Köppen. Instituto de
Geografía, Universidad Nacional Autónoma de México, Mexico City, Mexico.

Garibaldi, A., and N. Turner. 2004. Cultural Keystone Species: Implications for Ecological Conservation and Restoration. Ecology and Society 9:1-18.

Available at: http://www.ecologyandsociety.org/ vol9/iss3/art1. Accessed on November 30, 2017.

Giménez, G. 1994. Comunidades Primordiales y Modernización en México. In Modernización e Identidades Sociales, edited by G. Giménez and R. Pozas, pp. 151-163. Universidad Nacional Autónoma de México, Mexico City, Mexico.

Guzmán-Gómez, E., and A. León-López. 2014. Peculiaridades Campesinas del Morelos Rural. Economia, Sociedad y Territorio 14:175-200. Available at: http://www.redalyc.org/ pdf/111/11129102011.pdf. Accessed on December 1, 2017.

Haenn, N. 1999. The Power of Environmental Knowledge: Ethnoecology and Environmental Conflicts in Mexican Conservation. Human Ecology 27:477-491. Available at: http://www.jstor.org/ stable/4603330. Accessed on December 1, 2017.

Heckathorn, D. 2002. Respondent Driven Sampling Ii: Deriving Valid Population Estimates from Chain-referral Samples of Hidden Populations. Social Problems 49:11-34. Available at: http:// www.respondentdrivensampling.org/reports/ RDS2.pdf. Accessed on December 2, 2017.

INEGI. 2015. Anuario Estadístico y geográfico de Morelos. Instituto Nacional de Estadística y Geografía, Mexico City, Mexico.

Kellert, S. R., J. N. Mehta, S. A. Ebbin, and L. L. Lichtenfeld. 2000. Community Natural Resource Management: Promise, Rhetoric, and Reality. Society and Natural Resources 13:705-715. DOI:10.1080/089419200750035575.

López-Medellín, X., L. B. Vázquez, D. ValenzuelaGalván, E. Wehncke, B. Maldonado-Almanza, and L. Durand-Smith. 2017. Percepciones de los Habitantes de la Reserva de la Biósfera Sierra de Huautla: Hacia el Desarrollo de Nuevas Estrategias de Manejo Participativo. Interciencia 42:8-16. Available at: http://www.redalyc.org/articulo.oa? id $=33949290002$. Accessed on December 4, 2017.

Marques, J. 2001. Pescando Pescadores: Ciência e Etnociência em uma Perspectiva Ecológica. Núcleo de Apoio à Pesquisa sobre Populações 
Humanas e Áreas Úmidas Brasileiras, São Paulo, Brazil.

Medina, A. 1995. Los Sistemas de Cargo en la Cuenca de México: Una Primera Aproximación a su Trasfondo Histórico. Alteridades 5:7-23. Available at: http://www.redalyc.org/articulo.oa? $\mathrm{id}=74711352002$. Accessed on December 4, 2017.

Medina, A. 1996. Prólogo. In Introducción al sistema de cargos, edited by L. Korsvaek, pp. 2-15. Universidad Autónoma del Estado de México, Mexico City, Mexico.

Oehmichen, C. 2000. Las Comunidades Extendidas: Propuestas Para una Reflexión Antropológica. Revista Antropológicas 17:49-57.

Ortega-Argueta, A., A. González-Zamora, and A. Contreras-Hernández. 2016. The Framework and Indicators for Evaluating Policies for Conservation and Development: The Case of Wildlife Management Units in Mexico. Environmental Science and Policy 63:91-100. DOI:10.1016/ j.envsci.2016.05.003.

Pérez-Jiménez, L. A., A. Flores-Castorena, and G. Soria-Rocha. 1992. Clave Para las Familias de Plantas con Flores de la Sierra de Huautla, Morelos, México. Universidad, Ciencia y Tecnología 2:25-50.

Ramires, M., M. Clauzet, M. M. Rotundo, and A. Begossi. 2012. A Pesca e os Pescadores Artesanais de Ilhabela (SP), Brasil. Boletim do Instituto de Pesca 38:231-46. Available at: http:// www.pesca.sp.gov.br/38_3_231-246.pdf. Accessed on December 4, 2017.

Robles-de Benito, R. 2009. Las Unidades de Manejo para la Conservación de Vida Silvestre y el Corredor Biológico Mesoamericano México. Comisión Nacional para el Conocimiento y Uso de la Biodiversidad, Mexico City, Mexico.

Robson, J., and F. Berkes. 2011. How Does Outmigration Affect Community Institutions? A Study of Two Indigenous Municipalities in Oaxaca, Mexico. Human Ecology 39:179-190. DOI:10.1007/ s10745-010-9371-x.

Rubio-Becerra, R. E. 2012. Propuesta de UMA de la Especie Phrynosoma Orbiculare en el Centro de Enseñanza Investigación y Extensión en Producción AgroSilvo Pastoril (C.E.I.E.P.A.S.P.), de la UNAM. Unpublished Bachelor's Thesis. Universidad Nacional Autónoma de México, Mexico City, Mexico.
Saldaña-Fernández, C., D. I. Munévar, A. OrtízSánchez, E. E. Moreno, and A. N. AragónCadenas. 2007. Una Visita a la Reserva de la Biósfera Sierra de Huautla (Morelos, México). Estudios Sociales 1:189-219. Available at: http:// www.publicaciones.cucsh.udg.mx/pperiod/ estsoc/pdf/estsoc_07/estsoc07_189-219.pdf. Accessed on December 3, 2017.

Sánchez-Saldaña, K. 2008. Cosechas y peones en Morelos: especialización y segmentación en los mercados de trabajo rural. Análisis Económico XXIII: 201-225. Available at: http:// www.redalyc.org/articulo.oa?id=41311449010. Accessed on December 5, 2017.

Secretaría de Marina y Recursos Naturales (SEMARNAT). 2015. Sistema de Unidades de Manejo [web page]. Available at: http:// www.semarnat.gob.mx/temas/gestion-ambiental/ vida-silvestre/sistema-de-unidades-de-manejo. Accessed on November 3, 2015.

Spiegel, M. R., and L. J. Stephens. 2005. Estadística. Mac Graw-Hill, Mexico City, Mexico.

Statsoft. 2017. STATISTICA 8. Available at: http:/ / statistica.io/products/.

Trejo, I., and R. Dirzo. 2000. Deforestation of Seasonally Dry Tropical Forest: A National and Local Analysis in Mexico. Biological Conservation 94:133-142. DOI:10.1016/S0006-3207(99)001883.

Vandebroek, I., V. Reyes-García, U. Paulino de Albuquerque, R. Bussmann, and A. Pieroni. 2011. Local Knowledge: Who Cares? Journal of Ethnobiological Ethomedicine 7:1-7. DOI:10.1186/1746-4269-7-35.

Weber, M., G. García-Marmolejo, and R. ReynaHurtado. 2006. The Tragedy of the Commons: Wildlife Management Units in Southeastern Mexico. Wildlife Society Bulletin 34:1480-1488. DOI:10.2193/0091-7648(2006)34 [1480:TTOTCW]2.0.CO;2. 